TTR

Traduction, terminologie, rédaction

\title{
“Qui sont-je?” Multilingual Entanglements in Üstün Bilgen-Reinart's Porcelain Moon and Pomegranates: A Woman's Trek through Turkey
}

\author{
Eva C. Karpinski
}

Volume 31, numéro 2, 2e semestre 2018

Minorité, migration et rencontres interculturelles : du binarisme à la complexité

Minority and Migrant Intercultural Encounters: From Binarisms to Complexity

URI : https://id.erudit.org/iderudit/1065570ar

DOI : https://doi.org/10.7202/1065570ar

Aller au sommaire du numéro

Éditeur(s)

Association canadienne de traductologie

ISSN

0835-8443 (imprimé)

1708-2188 (numérique)

Découvrir la revue

Citer cet article

Karpinski, E. C. (2018). “Qui sont-je?” Multilingual Entanglements in Üstün Bilgen-Reinart's Porcelain Moon and Pomegranates: A Woman's Trek through Turkey. TTR, 31(2), 89-109. https://doi.org/10.7202/1065570ar
Résumé de l'article

Le « Qui sont je ? » d'Hélène Cixous marque le point de départ de cette étude sur les autotraductions plurielles de Üstün Bilgen-Reinart à la croisée des différentes cultures que l'auteure turco-canadienne a parcourues tout au long de sa vie qui, après l'avoir conduite au Canada, l'a ramenée en Turquie, son pays natal. J'ai lu son récit de voyage et de mémoire familiale translingue et hybride en vue de trouver la preuve des potentialités productives du multilinguisme dans les rencontres interculturelles. Les complexes enchevêtrements multilingues de ses langues, histoires, géographies imprègnent le texte pendant que l'auteure passe du turc à l'anglais et au français, en s'immergeant dans les témoignages en déné - langue des Dénés sayisi du nord du Manitoba -, et recueille des légendes kurdes du sud-est de l'Anatolie, traduites en turc. En collaboration avec Ila Bussidor, Üstün Bilgen-Reinart rédige, en 1997, Night Spirits, ouvrage qui raconte l'histoire orale de la relocalisation forcée suivie de la reconstruction de la communauté dénée. Après trente années passées au Canada, où elle a travaillé comme journaliste à la CBC, Üstün Bilgen-Reinart perçoit la situation actuelle en Turquie à travers les connaissances autochones auxquelles elle a été exposée et son adhésion au féminisme transnational. Son récit de vie offre une possibilité rarement donnée d'explorer les intersections d'histoires migrantes, diasporiques et autochtones à partir de la théorie affective des blessures du traumatisme, du déplacement et de la dépossession. Construisant un " Je »-témoignage (position of eye [I] witness) vis-à-vis des conséquences catastrophiques tant sociales, politiques, culturelles qu'écologiques de la mondialisation, son texte explore les enchaînements relationnels qui dépassent le soi singulier et créent des connexions entre les corps, les vies et leurs environnements. Son texte peut être lue sous l'angle d'une mise en langage décolonisée et multilingue.
Ce document est protégé par la loi sur le droit d'auteur. L’utilisation des services d’Érudit (y compris la reproduction) est assujettie à sa politique d'utilisation que vous pouvez consulter en ligne.

https://apropos.erudit.org/fr/usagers/politique-dutilisation/ 


\title{
“Qui sont-je?” Multilingual Entanglements in Ústün Bilgen-Reinart's Porcelain Moon and Pomegranates: $A$ Woman's Trek through Turkey
}

\author{
Eva C. Karpinski \\ York University
}

\begin{abstract}
Hélène Cixous's question "Who are I?" sets up the scene of this inquiry into the Turkish-Canadian writer Üstün Bilgen-Reinart's plural self-translations at the crossroads of different cultures she has traversed during her life trajectory from Turkey to Canada and back to Turkey. I read her hybrid translingual family memoir-travel narrative for evidence of productive potentialities of multilingualism in cross-cultural encounters. Woven into the text are complex multilingual entanglements of her many languages, histories, and geographies, as she passes from Turkish to English and French while immersing herself in the stories told in Dene, the language of the Sayisi Dene in northern Manitoba, and collects Kurdish stories from southeastern Anatolia, translated into Turkish. In 1997, with Ila Bussidor, Üstün BilgenReinart co-authored Night Spirits, an oral history of the forcible relocation and subsequent rebuilding of the Sayisi Dene community. Bilgen-Reinart's perception of the present-day situation in Turkey, after her thirty-year stay in Canada where she worked as a CBC journalist, is influenced by Indigenous knowledges that she has been exposed to and by her transnational feminist consciousness. Her life writing affords a unique possibility for exploring the intersections of migrant, diasporic, and Indigenous histories through affective theorizing of the wounds of trauma, displacement, and dispossession. Constructing the "I"-witness position vis-à-vis the disastrous social, political, cultural, and ecological consequences of colonialism and globalization, her text explores relational linkages that extend beyond the singular self and create connections between multiple bodies, lives, and their environments. Her practice of drawing complex webs of meaning can be read in terms of decolonial multilingual languaging.
\end{abstract}

Keywords: multilingualism, translation, Turkish-Canadian life writing, Indigeneity, transnational feminism, decolonial theories 


\section{Résumé}

Le «Qui sont je ?» d'Hélène Cixous marque le point de départ de cette étude sur les autotraductions plurielles de Üstün Bilgen-Reinart à la croisée des différentes cultures que l'auteure turco-canadienne a parcourues tout au long de sa vie qui, après l'avoir conduite au Canada, l'a ramenée en Turquie, son pays natal. J'ai lu son récit de voyage et de mémoire familiale translingue et hybride en vue de trouver la preuve des potentialités productives du multilinguisme dans les rencontres interculturelles. Les complexes enchevêtrements multilingues de ses langues, histoires, géographies imprègnent le texte pendant que l'auteure passe du turc à l'anglais et au français, en s'immergeant dans les témoignages en déné - langue des Dénés sayisi du nord du Manitoba -, et recueille des légendes kurdes du sud-est de l'Anatolie, traduites en turc. En collaboration avec Ila Bussidor, Üstün Bilgen-Reinart rédige, en 1997, Night Spirits, ouvrage qui raconte l'histoire orale de la relocalisation forcée suivie de la reconstruction de la communauté dénée. Après trente années passées au Canada, où elle a travaillé comme journaliste à la $\mathrm{CBC}$, Üstün Bilgen-Reinart perçoit la situation actuelle en Turquie à travers les connaissances autochones auxquelles elle a été exposée et son adhésion au féminisme transnational. Son récit de vie offre une possibilité rarement donnée d'explorer les intersections d'histoires migrantes, diasporiques et autochtones à partir de la théorie affective des blessures du traumatisme, du déplacement et de la dépossession. Construisant un «Je»-témoignage (position of eye [I] witness) vis-à-vis des conséquences catastrophiques tant sociales, politiques, culturelles quécologiques de la mondialisation, son texte explore les enchaînements relationnels qui dépassent le soi singulier et créent des connexions entre les corps, les vies et leurs environnements. Son texte peut être lue sous l'angle d'une mise en langage décolonisée et multilingue.

Mots-clés: multilinguisme, traduction, récit de vie turco-canadien, indigenéité, féminisme transnational, théorie décoloniale

\section{Introduction}

In pursuing the promise of productive potentialities of multilingualism generated by transnational movement and cross-cultural encounters, I open with Hélène Cixous's pluralizing question "Qui sont-je?" [Who are I?] and its homophone version "qui songe?' ('who muses/dreams/contemplates')" (2008, p. 47, n. 23). While the question starts with the subject-appropriately so, since I am dealing with a life writing text here-at the same time it already gestures beyond the unitary autobiographical "I" and shifts focus from individual subjectivity towards relationality. Suggesting a plurality of selves, or rather the self as a plurality "of echoes, of narratives, [and] autobiographies" (ibid., p. 34), her question not only troubles the container notion of the subject, but also foregrounds the need for 
active engagement with the world, for thinking that contemplates and imagines better possibilities for connection. Turkish-Canadian writer Üstün Bilgen-Reinart's translingual life writing in Porcelain Moon and Pomegranates: A Woman's Trek through Turkey (2007) responds to the ethical exigencies of the moment by constructing the "I"-witness position vis-à-vis what she perceives as the disastrous social, political, cultural, and ecological consequences of colonialism and globalization. I read her text to explore complex multilingual entanglements that extend beyond the singular, autonomous self and create connections between different bodies, lives, environments, and their plural languages, cultures, politics, histories, and geographies.

Bilgen-Reinart's memoir provokes several questions that organize my thinking and discussion below: How can her seemingly monolingual text be hospitable to multilingualism? How can a translingual text written in English by a multilingual subject be read as a complex multilingual environment in itself? How can it be read nonreductively against a default position of monolingualism? Addressing the multilingual turn in translation studies, Aurelia Klimkiewicz acknowledges the role played by global, transnational, and digital shifts in movement and communication that have revealed the insufficiency of translation as a paradigmatic model of cross-cultural encounter, with its underlying assumptions of coherence between language, culture, and territory $(2013$, p. 9). In a parallel development, hyphenated models of cross-cultural contact premised on immigrant and diasporic identifications (privileging translation within binary-oriented multicultural accommodation) have shifted towards transnational, mobile, hybrid, migrant intersubjectivities that call for more multidimensional understandings. I argue that in such diversified transnational contexts, multilingual languaging ${ }^{1}$ as a way of meaning-making occurs at every step of Bilgen-Reinart's creative process materialized in her published text: when inputting her personal experiences, interviewing people, collecting and translating research data, making all stylistic and lexical choices, and negotiating genre, politics and ethics. Accordingly, multilingualism here is more than the textual evidence of the presence of multiple languages but is fundamentally linked to the heterogeneous condition of the

1. "Languaging" is the term first developed by Chilean biologist Humberto Maturana in his early book Biology and Cognition (1970). It has recently been embraced in affect studies to convey the understanding of language as a wholebody, affective, socio-culturally embedded activity of meaning making. 
writing subject, her language, and the world she inhabits. My use of the concept of "multilingual entanglement" both as a descriptive framework for texts arriving from multilingual environments and as a practice of reading responds simultaneously to the changed geopolitical and communicative global context and to the parallel need for a methodology that would enable complex readings, readings that would attend to nuanced and multifaceted aspects of texts such as Bilgen-Reinart's hybrid narrative. In this context it is not surprising that many scholars of multilingualism appreciate the renewed relevance of Mikhail Bakhtin's dialogism (1981) which has laid the as-yet unsurpassed foundation for thinking linguistic complexity, recognizing that linear binary models always operate within and are affected by complex fields that are heterogenous and multilingual. ${ }^{2}$

Hybridity and heterogeneity are the dynamic forces behind Bilgen-Reinart's cross-genre family memoir/travel narrative/journalistic reportage. One can find the most accurate emblem for this book embedded in an ekphrastic passage that is part of the author's exposé of the GAP's (the Southeastern Anatolian Project) plans to bring dams and power stations to the underdeveloped and impoverished, mostly Kurdish, area of Upper Mesopotamia. Grieving over the fate of the Roman mosaics in the city of Zeugma that will be lost forever to flooding, and looking in particular at the mosaic pieces depicting Dionysos, Nike, Bacchae, Pasiphaë, Eros, and Venus, which archeologists desperately rush to salvage, Bilgen-Reinart observes that these " $\mathrm{t}]$ iny stones are laid in such a way that they convey movement and emotion" (2007, p. 171). Indeed, "movement and emotion" conveyed through small, self-contained vignettes seems to be an apt description of the affective structure of her book which is full of compassion, wonder, mourning, and rebelliousness.

Bilgen-Reinart inhabits an interesting site at the crossroads of "differently ranked" (Tlostanova, 2017, p. 19) major and lesser, former and present, colonial empires-each with its own imperial

2. One notable example of drawing on Bakhtin in conjunction with complexity theory and ecological approaches to language is Claire Kramsch and Anne Whiteside's analysis of "aspects of language use in multilingual settings" (2008, p. 646) which, in addition to tell-tale traces of other languages, views language use by transnational subjects as intrinsically multilingual: a synchronic discursive event linked to different layers of historicity, to other timescales, intertextualities, subjective resonances of affect and memory, and such "macrophenomena" as ideology and cultural values that always allow for new adaptations to emerge (ibid., p. 657). 
monolanguage of violence, greed, and profit. They include the British Empire that laid the foundations for Canada's settler-colonialism; the Ottoman Empire, existing since the $14^{\text {th }}$ century till its decline during World War I, its memories still alive in Turkey; and the U. S. global empire dominating the world's politics and economy today. Redrawing geopolitical borders, these modern engines of colonial expansion have left behind a trail of genocide, ethnic strife, and competing nationalisms. However, they seem young compared to the ancient empires of Mesopotamia: Sumerians, Babylonians, and Assyrians are also richly invoked in this travel narrative. Overall, Bilgen-Reinart shares what Françoise Lionet and Shu-mei Shih (2005) call the "dystopic vision of globalization" (2005, p. 6); she rails against Americanization and transnational capital that through the International Monetary Fund's loans has "reduced Turkey to a colony" and enabled "the corruption wreaking havoc" with its economy at the same time as "transnational corporations [are] spoiling the land and the water in Anatolia" (Bilgen-Reinart, 2007, pp. 23-24). Nevertheless, she clearly indicates that old imperial attitudes persist in the secular Republic of Turkey which since the 1920s has been denying the Armenian genocide and still continues its military repression of Turkish Kurds and occupation of Cyprus and of northern Syria.

Bilgen-Reinart's life trajectory takes her from Turkey to Canada and back to Turkey; she spends several years and sometimes months in places as diverse as Winnipeg, northern Indigenous settlements in Manitoba, Quebec City, and Ankara. She came to Canada as a student in 1977 at the age of eighteen; married a Canadian man; worked as a broadcaster and producer for the CBC in Winnipeg; was widowed at the age of thirty; remarried a francophone man and moved to Quebec City, where she adopted French as her third language; and eventually accepted a teaching job at METU (Middle East Technical University) in Ankara. After taking her teaching job, she and her husband have enjoyed the privileges of a transnational lifestyle, keeping one home in Quebec City and another in Ankara, and going back and forth between the two places (Bilgen-Reinart, 2007, p. 15). As she explains, her motivation for going back to her country of origin after more than thirty years in Canada was part nostalgia and part desire to find words to connect her two worlds (ibid., p. 12), so as to understand for herself the changes in contemporary Turkey and "try to reduce the 'otherness' of the 
Turks" (ibid., p. 15) in the eyes of Canadians (to whom this book is ostensibly addressed). Mythologizing Anatolia, its history and prehistory accumulated through "layers of civilization-the Stone Age, the Bronze Age, the Hattis, the Hittites, the Phrygians, the Lycians, the Ionians, the Romans, the Byzantines, et cetera, et cetera" (ibid., p. 16), are juxtaposed with what she perceives as Canada's absence of history. Consequently, while Anatolia is associated with archeology and ancient civilizations, Canada is seen through the lens of contemporary social issues that she reported on while working for the CBC (ibid., p. 13).

Multilingual entanglements are woven into the text through her personal and collective genealogies and local and global histories. Bilgen-Reinart's biographical circumstances have led her to become a translingual journalist and author who writes and publishes in English, and who also carries the family legacy of multilingualism: her paternal grandmother and her father each spoke five languages. ${ }^{3}$ She linguistically passes from Turkish to English and French while immersing herself in the stories told in Dene and Kurdish, both of which she can access only through translation. In the 1990s, Bilgen-Reinart co-authored Night Spirits (2000) with Ila Bussidor, a member of the Sayisi Dene Indigenous community. The book is an oral history of the forcible relocation of the Sayisi Dene that had a detrimental impact on their culture, language, and connection to nature. Bilgen-Reinart met Bussidor in 1985 while working as a current affairs reporter for CBC Television in Winnipeg, after she had been asked to cover the story of the Dene community's successful return to the land at Tadoule Lake, in northern Manitoba, "where people were gradually rebuilding their lives" (Bussidor and Bilgen-Reinart, 2000, p. xii). In 1956, the Canadian Government forcibly relocated the Dene population from their ancestral lands to the outskirts of Churchill, destroying their traditional way of life and ability to sustain themselves; families were torn apart through violence, addiction, and despair. In the early 1970s, a group of about 300 survivors set up a new community, moving $250 \mathrm{~km}$ away from Churchill in order to relearn their caribou hunting skills, revive their culture, and heal the wounds of racism and isolation. After years of difficulties, in 1995 they began to administer their own health,

3. Her paternal grandmother spoke French, Russian, Arabic, Greek, and Turkish (Bilgen-Reinart, 2007, p. 110); her father spoke five languages: Greek, French, German, English, and Turkish (ibid., p. 26). 
education, and community programs. For the Dene, the brutal displacement that forced them into the colonial matrix and ruined the ecological balance between the humans and their environment has been transformed into the community's resurgence and the revitalization of their livelihood and cultural practices.

\section{Lines of Flight}

Bilgen-Reinart's retelling of the Dene people's process of retranslating the community of survivors from the degraded urban setting of Churchill to the reclaimed land of Tadoule Lake, where they began their healing and community regeneration, mirrors her own repatriation to and repossession of Turkey. However, "repossession" is not the right word here since she constantly deterritorializes herself. As a traveller and narrator, she is always on the move, practicing the flickering, back and forth movement of cognitive and emotional displacement, deliberately embracing the position of an "outsider within," to use Patricia Hill Collins's (2000) term, ${ }^{4}$ which gives Bilgen-Reinart a certain epistemic advantage. It is connected to the possibility of finding her own "lines of flight" (Deleuze and Guattari, 1987 , p. 4) within the double (or triple) colonial matrix that situates her narrative as a Canadian, Turkish, and global female subject (where each of these categories is already heterogeneous, fractured, and non-unitary). In Gilles Deleuze and Félix Guattari's (1987) antibinary and nonlinear rhizomatic model of thinking and analysis, "lines of flight" (in French, lignes de fuite, where fuite can mean running away, flight, evasion, or leakage) are a means of escape from rigid systems and structures. Lines of flight offer multiple entries and exits, rupturing signification, deterritorializing meaning, putting one always in relation with the outside, in accordance with the principles of connection, heterogeneity, and multiplicity of becomings and possible materializations (ibid., pp. 4-9). For Bilgen-Reinart, the spatialtemporal movement characteristic of the convention of travel writing translates into the mobility of thought and emotion that allows her to cultivate her outsider-within stance, "resisting new attachments" (Bilgen-Reinart, 2007, p. 30) and letting go of essentialisms.

4. Hill Collins derives the concept of "outsider within" from the status of Black women and their marginalized position in domestic work performed for white families. This location of being outsiders within dominant spaces can be used creatively to stimulate new insights and "foster new angles of vision on oppression" (Hill Collins, 2000, p. 11) 


\section{Outsider Within}

The opening sentence of Bilgen-Reinart's book-"I wake up disoriented in the small hours of the night" (ibid., p. 11) - already establishes disorientation as an epistemological necessity in navigating the distance between Winnipeg and Ankara. She immediately articulates her outsider-within standpoint through continuous selfdisplacement:

In Ankara I speak Turkish without a foreign accent, but my love for Canada - my habits and values formed in that northern countrymake me a foreigner. In Quebec I spoke French with an accent and was considered Anglophone. My dearest friends and most cherished memories are in Winnipeg. My sons live in Vancouver and Toronto. (ibid., p. 12).

In fact, in Quebec she became "a double 'outsider'-an Anglophone woman of Turkish origin" (ibid., p. 14). Alternately a tourist and a resident in Turkey, she experiences her native country through "the mixture of foreignness and familiarity" (ibid., p. 18). To maintain an outsider-within stance requires a constant methodological strategy of deterritorializing from mainstream locations and dominant perspectives. Negotiating between her plural selves sometimes results in the seemingly incompatible logic of either/both. Thus, for example, while on the one hand she admits to being motivated in writing her account by a desire to challenge the negative stereotypes of Turkey as the exotic distant "other" in the eyes of Canadians, on the other hand, she concedes in front of the same Canadian readers that Turkey's record of "human-rights violations, ethnic repression, and the suppression of women" is well documented (ibid., p. 20).

Bilgen-Reinart keeps returning to the issue of "ethnic nationalism" whether in 1990s Quebec, where it influenced discourses about identity, or in Turkey, where "ethnic diversity is a taboo subject" (ibid., p. 15) due to Kurdish separatism and a long history of ethnic repression by the state that refuses to grant legal rights to minorities. The outsider-within standpoint allows her to develop a non-essentialist view of ethnicity, which is partly related to the legacy of her paternal grandmother Lemonya, an Anatolian Greek who converted to Islam when she married a Muslim man. Until she became an adult, the author and her siblings did not know that her grandmother was "Rum (Anatolian Greek)" and that her name meant "lemon tree" in Greek (ibid., p. 99). While they were growing up, the 
grandmother's real "ethnic identity was kept secret" from her own grandchildren, not to "taint" them with the heritage of Byzantium (ibid.). However, the author embraces this heritage, along with many other subalternized histories in Turkey, and describes herself as a living contradiction: a "Turk" who along with "the Western world still mourns the fall of Constantinople to the hated Turks" (ibid., p. 100).

\section{Feminist Decolonial Transnationalism}

As she physically and emotionally navigates simultaneous belonging and her identifications as Canadian immigrant, Turkish expatriate, and cosmopolitan citizen, Bilgen-Reinart's life writing affords the possibility for exploring multilingual intersections of migrant, settler-colonial, global diasporic, and Indigenous histories. I would argue that her critical angle in braiding together these various strands of multilingual stories might be labelled as feminist decolonial transnationalism which, expanding on transnational feminism to include non-western Eurocentric epistemologies, links colonialism, militarism, and neoliberal capitalism to the destruction of women, Indigenous peoples, and the land, in Canada, Anatolia, and in the global world. To understand Bilgen-Reinart's affinities with transnational feminism, one can recall that its mandate, as elaborated by Caren Kaplan and Inderpal Grewal, was precisely to examine the linkages and connections among nations, heteropatriarchies, colonialisms, and militarisms, viewing regional and local contexts as permeated simultaneously by national and global political, economic, and cultural powers. In formulating their theory of transnational feminist cultural studies, Kaplan and Grewal recognize that "[critical] practices are always negotiated in both a connected and a specific field of conflict and contradiction" (1999, p. 358) and that they are linked to one's understandings of postmodernity, global economic structures, nationalism, race and imperialism, global feminism, and historical and emergent patriarchies.

Furthermore, decolonial scholars like Walter Mignolo (2003) and Sylvia Wynter (1997) — calling for a delinking from the modernity/coloniality paradigm - provide the language for a radical critique of Western instrumental colonial rationality that suppresses non-European, heterogeneous ways of being and knowing. Wynter in particular exposes the detrimental effects of this "cognitive closure" (1997, p. 549) on the eco-cultural and epistemic specificity 
and heterogeneity of human and non-human co-habitation of the planet. Combining these frameworks, of transnational feminism and decolonial thought, offers potent tools to defamiliarize universalized and normalized views - whether they appear in the form of Canadian settler-colonial or Turkish state-hegemonic assumptions-and to develop solidarity and community with subalternized knowledges and peoples. Aligning herself with liminality, Bilgen-Reinart is drawn to stories of those who have been silenced, oppressed, marginalized and excluded, who have suffered within different imperial/colonial matrices of domination. In that, her stance in Porcelain Moon and Pomegranates harks back to her collaboration with her Dene friend Bussidor in Night Spirits, where they enact a transversal model of solidarity across the differences of coloniality, race, culture, language, and history.

Exemplifying "decolonial relational complexity" in her narrative (Tlostanova, 2017, p. 24), Bilgen-Reinart transitions from the role of a sympathetic outsider who lends her exceptional writing skills to transmit her friend and Indigenous informant's experiences of the violence of relocation, to the role of an outsider-within reporting on what she calls the "dark stories" (Bilgen-Reinart, 2007, p. 215) in her native Turkey. In addition to the tragic family history that involves her great-grandparents expulsion from Greece, her grandmother's religious conversion and subsequent abandonment by her husband, ${ }^{5}$ she includes several chapters derived from her fieldwork in different parts of Anatolia. Other pieces of her dark mosaic include narratives based on her befriending and interviewing women from a brothel in Ankara; a chapter describing her meetings with families of victims of honour killings; another one that documents her encounters with Kurdish refugees in the squatter houses of Diyarbakir in southeastern Anatolia, and visits to the war zone of Kurdish guerrilla resistance to the Turkish army, where she talks to both sides, soliciting chilling stories; there is her coverage of the sites of ecological and human disaster caused by the government's programmatic flooding of

5. Incidentally, the black-and-white photograph showing this grandfather sitting next to the author's father as a child wrapped in the Turkish flag is featured on the cover of the book, just below a contemporary colour shot of Bilgen-Reinart posed in a tourist fashion on a bench overlooking the Ishak Pasha palace, captioned on the back cover as "a superb example of seventeenth/eighteenth-century Ottoman architecture."These images remind us of what Kramsch and Whiteside refer to as the "subjective, embodied time of cultural memory" (2008, p. 658) that forms the affective axis of this life writing text. 
Kurdish villages in the Tigris and Euphrates crescent, in the region replete with archeological treasures; and, finally, her indictment of the government's accommodation of the interests of transnational gold mining corporations that destroy "pine forests, vineyards, and olive groves" (ibid., p. 232).

The adoption of an outsider-within perspective in most of these accounts allows her to performatively enact an ethics of cross-cultural encounter that demands commitment to the following principles: (1) giving a careful hearing to another person's story; (2) refusing to speak for and instead giving voice to her subjects, whose names, and sometimes images, she meticulously records; (3) situating herself as a witness whose knowledge is limited and needs to be supported by extensive research and interviews; (4) providing detailed historical and political contexts; (5) and foregrounding multiple mediations in the transmission of the story, most notably, the flaunting of translation, reporting conventions, and cultural defamiliarization. As the narrator/protagonist of this travel memoir, she attempts to embody an ethos of journalistic reporting and life writing as selfreflexive practices, both of which must constantly be accountable to the challenges posed by exposure to trauma, contradictory politics, unequal power dynamics, appropriation, and cultural aporias. ${ }^{6}$

Building on her collaboration with Bussidor, she continues to forge feminist transnational solidarities with women's collectives in Turkey. In addition to speaking with sex workers sequestered in the Ankara brothel, she meets with women dancing dervishes of the mystic order of Mevlevi; Kurdish families of killed guerilla soldiers; parents of girls and women who were victims of honour killings, murdered by their fathers, husbands, and brothers; and peasant grass-roots activists protesting the gold mines that poison the fertile soil of the northern Aegean coast with cyanide. She bears witness and documents resistance to military and sexist state-sanctioned abuses of power, and in the process befriends women activists from the charitable Kurdish organization Women's Platform (Bilgen-

6. Yet, there are a few lapses in the feminist ethics of her engagements, moments of failed translation bordering on discursive violence. One is the incident with a hijab, in which she reports a Muslim student in her class for wearing a religious head covering against strictly secular academic regulations (Bilgen-Reinart, 2007, p. 137). Another is an instance of romanticizing a poor homeless prostitute as a "defeated Amazon" (ibid., p. 68). Finally, she has made a questionable decision to reproduce, apparently without permission, a personal photograph of Hacer, a brothel employee portrayed in a rather unflattering way (ibid., p. 87). 
Reinart, 2007, p. 152); from the Bureau of the Status of Women in Ankara, which fights the laws that limit women's rights; and from a feminist collective called The Flying Broom, which supports women's shelters in Turkey. While observing these changes, she thinks of her mother, who was from a Muslim Turkish family, and who embodies the contradictions of femininity in Turkish society. Her mother belonged to the first generation of university-educated women who escaped the veil. Yet, despite her education as a lawyer, she dedicated herself primarily to the roles of wife and mother (ibid., p. 28).

\section{Finding the Goddess}

Bilgen-Reinart revisions her feminist genealogy by drawing on a few thousand years old Anatolian tradition of the great goddess cult. She quotes scholarship that claims that "Anatolia experienced a longer matrilineal (or woman-centred) period than other ancient societies in the Middle East" (ibid., p. 45). For her, archeological evidence of the continued worship of a goddess in the region inspires the vision of "a peaceful society" where femininity and sexuality were valued (ibid., p. 40). Therefore, on her treks through southeastern Anatolia, she follows the goddess, visiting archeological dig sites that have uncovered material traces of the goddess going back to the Neolithic period. The entire chapter dedicated to the goddess serves an important function of elevating an idealized ancient cult of femininity as a forfeited, alternative path of the human inhabiting of the planet, based on models of "partnership" rather than "domination" and on acceptance of diversity and free giving and receiving of sexual pleasure (ibid.). This project of excavating ancient memory is about dreaming an alternative history and empowering women, giving expression to a nostalgic utopia of the world "in which both men and women had high status" (ibid.), before militarized patriarchies were instituted in this region and initiated the repression of women that has continued to the present day. Significantly, in the same chapter, she voices the connection between the silencing of women and the Earth's ecological destruction, blaming "greedy and warlike empires" whose politics, in multiple incarnations, have led to pollution and other socio-political problems such as:

[t]he greenhouse effect. Droughts. Dioxins, PCBs, electromagnetic fields. Poverty. Corruption. Economic collapse. War fought over oil and gas in the Middle East and Central Asia. (ibid., p. 41) 
In the book dedicated "[t]o past, present, and future Anatolian women of all creeds," which privileges women's perspectives/standpoint throughout, the mythologized Anatolian past-standing in sharp contrast to the present-is an inspiration for her "to imagine differently, to build kinder societies" (ibid., p. 42). She is particularly fascinated with the legendary Amazons who, according to Herodotus, lived in Anatolia and worshipped the Greek Goddess Artemis in Ephesus (ibid., p. 45). A Turkish historian whom she interviews calls them "the most ancient and the most powerful women's movement in history" (ibid.). Digging into Anatolia's archeological and mythical legacy of matrilineal, goddess-worshipping civilizations allows Bilgen-Reinart to construct a bridge between a dignified past and a possible future, arching over the presentday reality of the region plagued by ethnic conflict, environmental damage, and the rise of political Islam in Turkey. The importance of this symbolic compensatory structure is reflected in the title images of pomegranates and the porcelain moon, both attributes of the goddess.

\section{Indigenization and Ecological Consciousness}

In addition to adopting the outsider-within standpoint, other lines of flight are available to her through indigenization and ecological consciousness. It is evident that she thinks through some concepts that she has learned from the Dene, frequently interpreting through them the situations encountered in Turkey. Bilgen-Reinart views women as "the bearers of collective memory" (2007, p. 17), similar to the women's role in the transmission of knowledge in Indigenous communities, which she had experienced first-hand while assisting Bussidor in conducting oral history interviews with Dene elders. Her reflection on "the suppression of female voices, female memories, and female sexuality in Anatolia" (ibid.) recalls settler-colonial patriarchal suppression of Indigenous women in Canada and the Indigenous themes of the centrality of women to a community's cultural and ecological survival: "I knew that in Canada, too. But it is only here [in Anatolia] that I begin to discern the relationship between ecological damage and the loss of distant memory" (ibid.) According to her, "[ $t]$ he killing of nature and the suppression of ancient memory are related to the silencing of women's voices," which is aimed at robbing them of their power and weakening their status (ibid.). However, when she reads Turkey through an Indigenous lens acquired in 
Canada, she sometimes risks producing ethically dubious effects as, for example, in identifying Nanabush, the Trickster, with an older sex worker whom she met in Municipal Hospital for Venereal Diseases:

Suddenly, I know who Naciye reminds me of. It's Nanabush, the trickster in Ojibwa mythology, as she was portrayed in Tomson Highway's play Dry Lips Oughta Move to Kapuskasing. Fat, worn, bitter, and wise - a joker who knows sorrow. (ibid., p. 84)

Still, she notes global continuities in the ubiquity of violence against women, as she collates stories of honour killings in southeastern Anatolia that resonate with her early recollection of standing "at the grave of a murdered Cree teenager, Helen Betty Osborne, at the Norway House Reserve in northern Manitoba" (ibid., pp. 11-12).

But mostly, it is Bilgen-Reinart's focus on ecology, inspired in part by her reporting on Indigenous issues, that leads her to detect global parallels between the environmental damage inflicted by both countries' extractive economies. Noticing similarities between the situation of Turkish villagers losing their lands to mining and the Indigenous people in Canada whose lands have also been destroyed by gold mines, she lets an elderly peasant woman bemoan water and soil contamination: "We were the keepers of the land. We were living off the land with the light of our eyes. We were the guardians of the earth. Away from the land we'll die" (ibid., pp. 199-200). Starting from the acknowledgement of the inextricable relationship between land and people (p. 14) and the link between ecological balance and survival (ibid., p. 17), the author remembers that even the goddess worship in Anatolia "was entrenched in the land," where Mountain Mother embodied "the connection between mountains and female breasts" (ibid., p. 34).

Grounded in Indigenous epistemologies, Bilgen-Reinart's ecological consciousness is linked to a critique of neoliberal capitalist expansion in Turkey, its opening to transnational capital that causes ecological destruction, loss of ancient material culture and memory, and the forced migration of expendable people such as Turkish villagers and Kurds. While she denounces "the frenzied plunder of resources that provokes war and damages ecological balance around the world" (ibid., p. 16), she finds bittersweet comfort in contemplating history's inevitable cycles:

Anatolia knows that empires fall. The Hittite Empire, the Roman Empire, the Ottoman Empire have all reigned here, and all of them 
have turned to dust. But the Empire of Market Forces that rules over the world in the twenty-first century, indifferent to life, environment, history, prehistory, and memory, possesses weapons capable of destroying the planet. (ibid., p. 235)

Consequently, she herself becomes an activist involved in the struggle for environmental protection and mentions that she has made a presentation at a parliamentary hearing on how a proposed new Turkish law on mining would violate European Union legislation (ibid., p. 233).

\section{Multilingual Languaging}

Bilgen-Reinart's performance of cross-cultural dialogue and multilingual networking appears to be a process that entails multiple foldings of bodies and environments, historically, geographically, and socio-politically localized and impacted by memory, individual and collective, which has left its imprints in language. She registers multilingual etymologies in different names given to the goddess by the Phrygians, who "called her Matar (Mother) or Matar Kubileya (Mountain Mother)" (Bilgen-Reinart, 2007, p. 17), or "Kubaba" in Hittite, and "Cybele" in Greek (ibid., p. 33). Her etymological parsing of the word "Amazon" reveals its inherent multilingualism in the proximity of multiple languages that inhabit the sound. The following passage illustrates both the deterritorializing movement of shifting semantics and an understanding of language as a rhizomatic relation:

The word Amazon has several possible roots. According to Herodotus in Histories, it may have some relationship to the word oior-pata, which means "man-slayers" in the Scythian language... The second [possibility] is that it may have been derived from the Greek a-mazos, which means "breastless", to describe the tribe of women who cut off their right breasts for the sake of archery. A third explanation connects their name to the word amissa (amissawana), which in the Luwite language means "land of the holy mother", and which became the name of a town on the Black Sea coast of Anatolia (today's Samsun) where the Amazons lived. (ibid., p. 65)

In the above example, thinking of language as a rhizome takes one beyond linguistics to semiotics and pragmatics, to contestations around power, gender, temporality, and geography. The fluidity of language allows her even to feminize Islam when she traces 
a connection to the goddess in the word "Kaab'a," the name of "a sacred black stone, a meteorite... a revered place of pilgrimage to Muslims, who still pray in the direction of something called Kible. Kaab'a, Kible, Kybele, Cybele" (ibid., p. 73).

The rhizomatic proliferation of differently rooted meanings, along with the palimpsestic presence of dead languages, the Ottoman echoes of Greek, Bulgarian, Armenian, and Ladino, and the muted refugee voices in Kurdish and Arabic that can be heard in Turkey today-all this suggests that there is no such thing as "a homogeneous linguistic community":

Language is, in Weinreich's words, "an essentially heterogeneous reality."There is no mother tongue, only a power takeover by a dominant language within a political multiplicity. Language stabilizes around a parish, a bishopric, a capital... It is always possible to break a language down into internal structural elements, an undertaking not fundamentally different from a search for roots... A method of the rhizome, on the contrary, can analyze language only by decentering it onto other dimensions and other registers. A language is never closed upon itself, except as a function of impotence. (Deleuze and Guattari, 1987, pp. 7-8)

In contrast to the politicized national monolanguage in Turkey, which recognizes only Turkish as its official language, in BilgenReinart's case, one might speak of multilingual languaging: a socially enacted, historically embedded, and politically situated networked process of sense-making that entails multiple and complex transfers of meaning, memories, affects, and sensory perceptions. Thinking in terms of languaging rather than language affords further departure from the concept of language as a bounded, symbolic, code-like system that can be put into multiple uses, reconceptualizing it as process, action, and dynamic interaction while also acknowledging the socio-cultural constraints on this activity (Jensen, 2014, p. 2). As an embodied and dialogical concept, "languaging"-used by Alton L. Becker-refers to "an open-ended process" that requires "attunement to context, storing and retrieving memories, and communication” (Becker qtd. in Chow, 2014, p. 125). In Bilgen-Reinart's memoir, an example of such complex transfers occurs in her process of interviewing Kurdish people, when she relies on a local translator who translates from Kurdish into Turkish the words that she then translates into English from a recording, allowing all three contexts to interact. 
It makes sense to consider Bilgen-Reinart's practice of multilingual languaging in conjunction with decolonial translation as both involve adaptive, flexible, affective responses to changing situations and new environments. Within the decolonial epistemologies of translation, developed by Mignolo and Schiwy (2003), translation is unsettled from hegemonic frameworks:

The theories of translation/transculturation [...] are coming from a critical reflection on the colonial difference and from seeking to overcome the national-language ideology frame in which translation was conceived, practiced and theorized in the modern/colonial world. Translation can no longer be understood as a simple question of moving from object language $\mathrm{A}$ to subject language $\mathrm{B}$, with all the implications of the inequality of languages. Rather, translation becomes a "translanguaging", a way of speaking, talking and thinking in between languages [...]. (Mignolo and Schiwy, 2003, p. 23)

Bilgen-Reinart's text moves from traditional binary notions of translation as a linear transfer between two discrete, relatively homogeneous monocultural entities premised on the ideas of interchangeability and equivalences even between asymmetrically weighted languages and cultures. Rather, her narrative, whose surface English is constantly punctured by eruptions of Turkish, French, Greek, Italian, Latin, and Arabic words and phrases, contains different potentialities of multilingual co-emergence, favouring more lateral, transversal, internally differentiated, and often non-translated multilingual contact and exchanges. Her decolonial translation as multilingual languaging performs such functions as: (1) exposing the consequences of colonial and neo-colonial rationality and its imperial mono-consciousness and global monolanguage; (2) thinking/ feeling/speaking from multiple locations on the model of translation as transculturation that involves merging and convergence of differences; and (3) fostering transversality of relations favoured by multilingual "minor transnationalisms" as theorized by Lionnet and Shih (2005). Lionnet and Shih have coined this term to move beyond the overdetermined majority-minority culture model in postcolonial studies, a version of which has also obtained in postcolonial translation studies. Minor transnationalism refers to practices of transnational contact and interchange between liminal groups, viewed through "the lens of minority populations" (Lionnet and Shih, 2005, p. 5). In Bilgen-Reinart's case, a good example of such "interaction of 'minor' peoples cross-culturally but within the same space" (ibid.) might be 
her alignment as a Turkish immigrant to Canada with the Dene survivors of the relocation. I would like to add that one of the merits of multilingual languaging is the possibility of replacing an ethics of identity with an ethics of identification, as seen in Bilgen-Reinart's facility for letting go of territorialized attachments and forming transnational feminist solidarities. Ultimately, her simple definition of translation as finding "words to connect" (Bilgen-Reinart, 2007, p. 12) becomes an ethical call to speak in the face of the unspeakable: of war trauma, ecological disaster, and cultural genocide, so as to find ways of bringing different worlds together and forging new relational ways of knowing and of surviving.

\section{Conclusion}

In conclusion, I want to offer a brief summary of some theoretical possibilities opened up by the above framework of multilingual languaging and decolonial translation. Bilgen-Reinart's text invites reflection on complex entanglements between multilingualism and translation. To paraphrase Paul Ricoeur's claim that there is translation because of the simple fact of "the plurality and diversity of languages" (2006, p. 11), translation exists because of multilingualism which provides its ontological base. Rather than speculating whether translation posits a threat to or even erases multilingualism, one might see translation itself as a form of multilingualism in that it involves an insertion of foreignness into a new relational space. By contrast, multilingualism is not necessarily hospitable to translation and can exist within a compartmentalized monolingual model insisting on strict separations between different languages. One of the writers showing the necessity of thinking beyond the no longer tenable opposition between mono- and multilingualism is Édouard Glissant, who believes that one speaks and writes "in the presence of all the world's languages" (1999, p. 119). He articulates the following relationship between translation and multilingualism:

Just as the writer now practices this totality [of languages] in the language he writes in, so does the translator manifest it in the passage from one language to another, confronted as he is with the singularity of each language [...]. [The translator] cannot establish a relation between two singular systems, between two individual languages, except in the presence of all the other ones, powerful in his imagination, even if he doesn't know any of them. (ibid., p. 121). 
Glissant's ideas echo Bakhtin's (1981) concepts of heteroglossia and polyglossia that refer to the inherent heterogeneity within every language and to the simultaneous interlingual co-existence of a multiplicity of languages. Bakhtin's dialogism enables a move away from the reductive ontologism of such concepts as language, culture, and identity, toward more process-oriented philosophies of languaging, performing, and becoming. As manifestations of human life and consciousness, language, culture, and identity are dynamic concepts, non-unitary but always already pluralized, internally differentiated, and heteroglossic in Bakhtin's terms. They are also dialogic in the sense of their specific social and historical situatedness, related to their particular moment and context. Since we can only exist in relational networks of signification and make sense of identity and culture only relationally, as Bilgen-Reinart's texts demonstrates, dialogue and relationality are fundamental, lifesustaining forces that can unsettle the centralizing and homogenizing hold of the colonial matrix.

Moving beyond text-based understandings of translation as a linear or bi-directional linguistic and cultural transfer between the source text and the target text, decolonial translation demands a different ethics of cross-cultural encounter, one which requires receptiveness to perspectives from below, hospitality to the heterogeneous within and without, and co-habiting in the discomfort of nontransparency. It draws attention to the ontologically complex status of translation that can more productively be seen as a multilingual entanglement of subjectivities, texts, languages, and contexts, open to different possible materializations realized through often unpredictable encounters between authors, translators, and audiences. In this sense, not just translation as border-crossing or the border itself, even as a geopolitical term, can be contested when viewed through the eco-cultural lens of connectivity and entanglement in the age of the Anthropocene, the era of significant human impact on the planet, when there is no inside and outside, no refuge, no lines of flight. Porcelain Moon and Pomegranates is Bilgen-Reinart's impassioned bricolage of environmentalism, anti-globalization, and transnational human rights for women, Muslims, ethnic and linguistic minorities, all interconnected through a complex web of multilingual encounters. Her decolonial feminist translation explodes the borders and takes us to the space where, rather than asking what translation re- 
conceived on the model of multilingual languaging is, we can see what it does, how it connects, whose interests it can serve, and what futures it imagines as possible.

\section{References}

Bakhtin, Mikhail (1981). The Dialogic Imagination: Four Essays. M. Holquist, ed. Trans. C. Emerson and M. Holquist. Austin, University of Texas Press.

Bilgen-Reinart, Üstün (2007). Porcelain Moon and Pomegranates: A Woman's Trek through Turkey. Toronto, Dundurn Press.

Bussidor, Ila and Üstün Bilgen-Reinart (2000). Night Spirits: The Story of the Relocation of the Sayisi Dene. Winnipeg, University of Manitoba Press.

Chow, Rey (2014). Not Like a Native Speaker: On Languaging as a Postcolonial Experience. New York, Columbia University Press.

Cixous, Hélène (2008). "In the beginnings, there were many..." An interview with Mireille Calle-Gruber. Trans. A. Damlé. In S. Sellers, ed. White Ink: Interviews on Sex, Text and Politics. New York, Columbia University Press, pp. 30-48.

Deleuze, Gilles and Félix Guattari (1987). A Thousand Plateaus: Capitalism and Schizophrenia. Trans. B. Massumi. Minneapolis, Minnesota University Press.

Glissant, Édouard (1999). "From Introduction to a Poetics of the Diverse." Trans. P. Joris. boundary 2, 26, 1, pp. 119-121.

Hill Collins, Patricia (2000). Black Feminist Thought: Knowledge, Consciousness, and the Politics of Empowerment. Revised $10^{\text {th }}$ anniversary edition. New York, Routledge.

Jensen, Thomas W. (2014). "Emotion in Languaging: Languaging as Affective, Adaptive, and Flexible Behavior in Social Interaction." Frontiers in Psychology, 5, pp. 1-14.

Kaplan, Caren and Inderpal Grewal (1999). "Transnational Feminist Cultural Studies: Beyond the Marxism/Poststructuralism/Feminism Divides." In C. Kaplan, N. Alarcon and M. Moallem, eds. Between Woman and Nation: Nationalisms, Transnational Feminisms, and the State. Durham, Duke University Press, pp. 349-363.

Klimkiewicz, Aurelia (2013). "Présentation." TTR, 26, 1, pp. 9-14.

Kramsch, Claire and Anne Whiteside (2008). "Language Ecology in Multilingual Settings. Towards a Theory of Symbolic Competence." Applied Linguistics, 29, 4, pp. 645-671.

Lionnet, Françoise and Shu-mei Shih, eds. (2005). "Introduction: Thinking through the Minor, Transnationally." In F. Lionnet and S. Shih, eds. Minor Transnationalism. Durham, Duke University Press, pp. 1-23.

Mignolo, Walter D. and Freya Schiwy (2003). "Double Translation: Transculturation and the Colonial Difference." In T. Maranhão 
and B. Streck, eds. Translation and Ethnography. The Anthropological Challenge of Intercultural Understanding. Tucson, University of Arizona Press, pp. 3-30.

Ricoeur, Paul (2006). On Translation. Trans. E. Brennan. London and New York, Routledge.

Tlostanova, Madina (2017). "Decolonizing East European Memory: Between Post-dependence Traumas and Neo-imperial Obsessions." In I. Gubenko, D. Hanovs and V. Malahovskis, eds. The New Heroes- the Old Victims: Politics of memory in Russia and the Baltics. Riga, Zinatne, pp. 16-27.

Wynter, Sylvia (1997). “Genital Mutilation' or 'Symbolic Birth'? Female Circumcision, Lost Origins, and the Aculturalism of Feminist/Western Thought." Case Western Reserve Law Review, 47, 2, pp. 501-552.

Eva C. Karpinski School of Gender, Sexuality and Women's Studies York University Toronto, Ontario, Canada evakarp@yorku.ca 